\title{
Quantifying present and future glacier melt-water contribution to runoff in a Central Himalayan river basin
}

\section{Supplementary Material}

M. Prasch ${ }^{1}$, W. Mauser ${ }^{1}$ and M. Weber ${ }^{2}$

[1]\{Department of Geography, LMU Munich, Germany\}

[2] \{Commission for Geodesy and Glaciology, Bavarian Academy of Sciences and Humanities, Munich, Germany\}

Correspondence to: M. Prasch (m.prasch@lmu.de)

\section{Contents}

1. Supplementary Figures

2. Supplementary Tables

3. Supplementary model details

4. Supplementary model validation of SURGES

References

\section{Page}

2

4

6

10

15 


\section{Supplementary Figures}
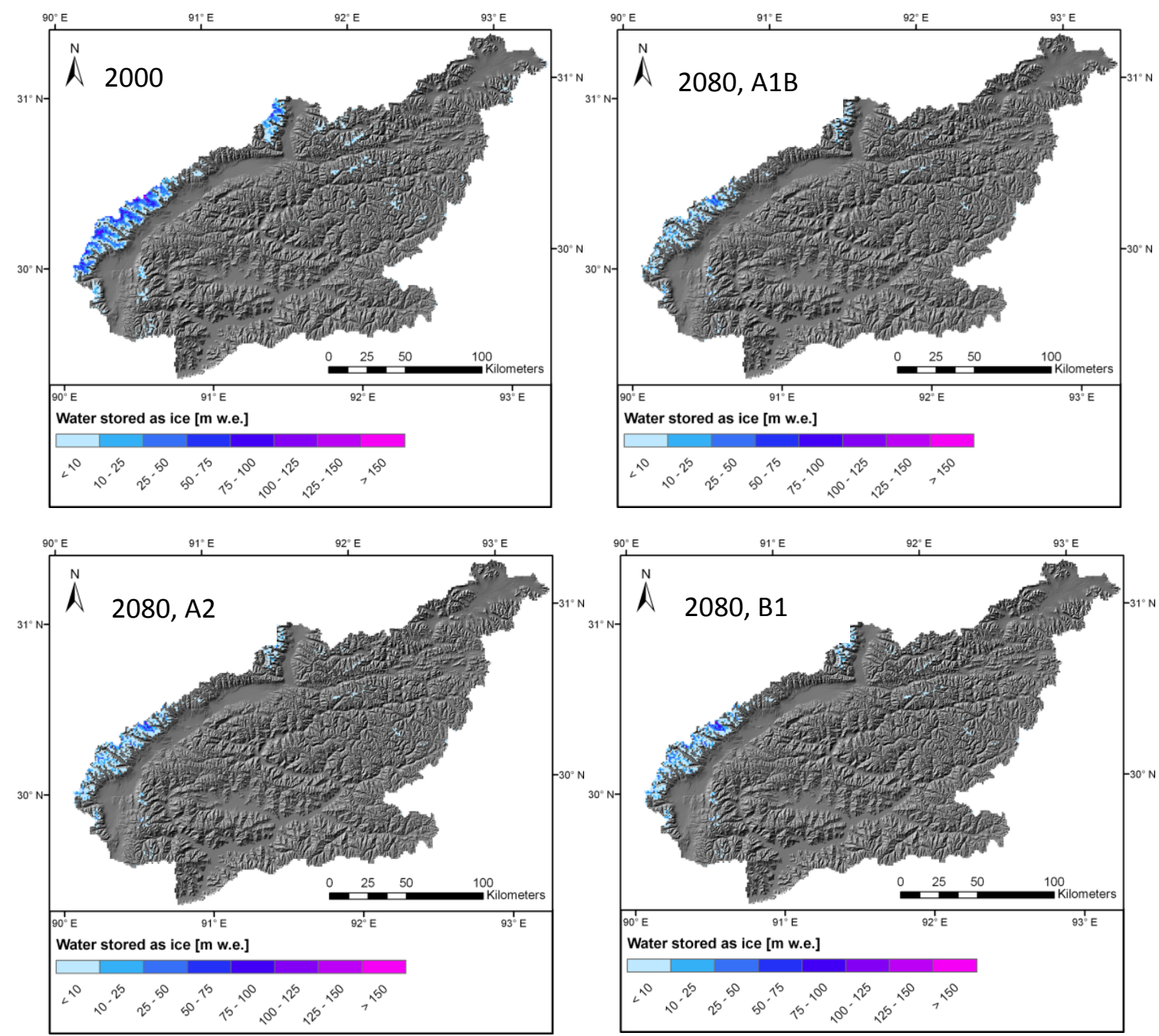

Figure S1: The spatial distribution of the simulated ice water equivalent in 2000 and 2080 according to the CLM ECHAM5 IPCC A1B, A2 and B1 driven scenario model runs. 

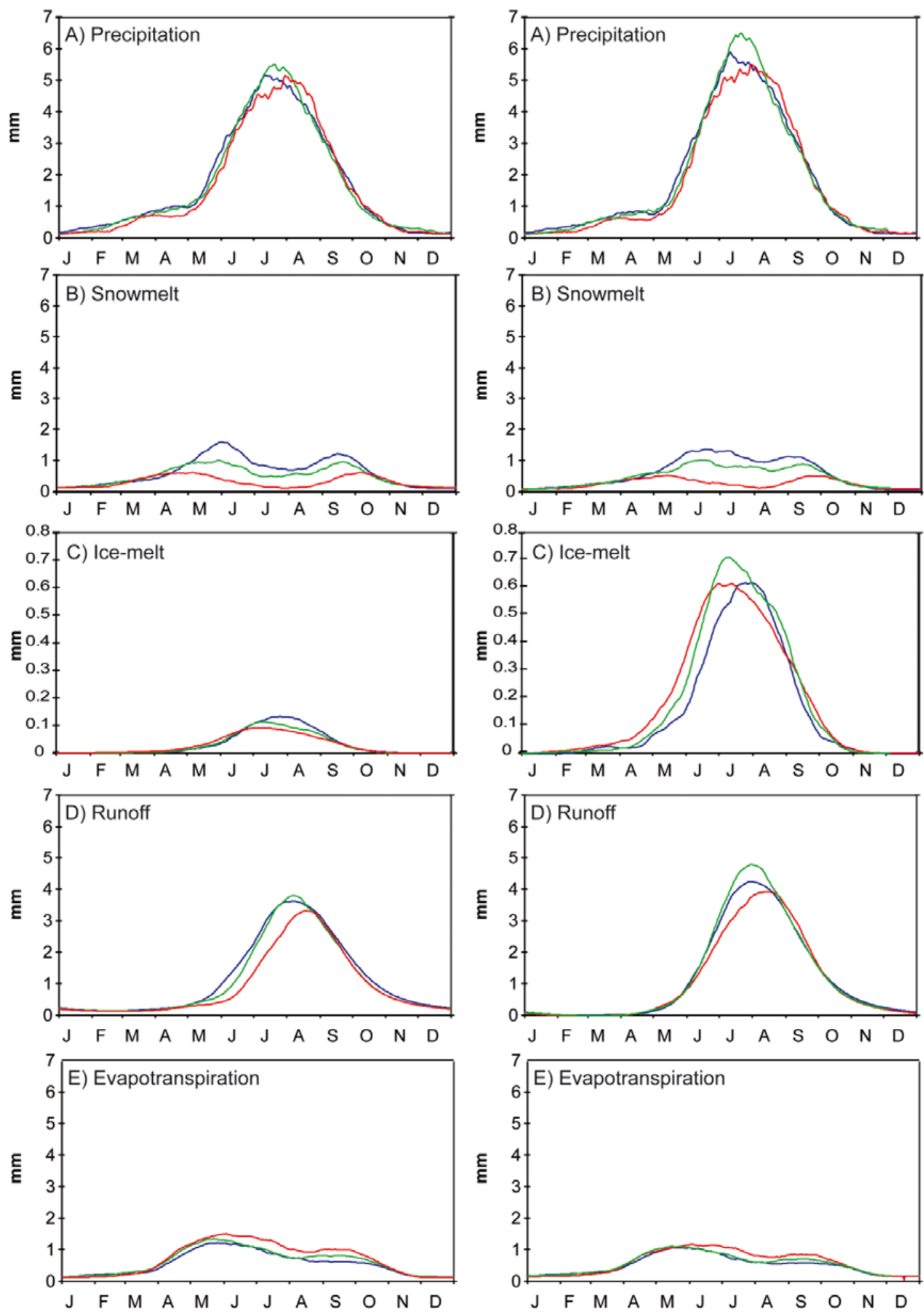

Figure S2: Average annual dynamics of daily different runoff components at the outlet of the LRB (left) and at Yangbajing (right) (moving average over 30 days); precipitation (A), snowmelt water release of the basin (B), ice-melt (C), river runoff (D), and evapotranspiration (E) for the periods 1971-2000 (blue), 2011-2040 (green) and 2051-2080 (red) are shown. 


\section{Supplementary Tables}

Table S1. Details of observed data at the meteorological and gauging stations, illustrated in Fig. 1 (data provided by ICIMOD and ITP).

\begin{tabular}{llll}
\hline Station & Observed value & Observation period & Temporal resolution \\
\hline Damshung & Air temperature & $1980-2000$ & Daily \\
& Precipitation & $1980-2000$ & Daily \\
Lhasa & Air temperature & $1980-2000$ & Daily \\
& Precipitation & $1980-2000$ & Daily \\
& Precipitation & $1971-2000$ & Monthly \\
& Runoff & $1971-2000$ & Monthly \\
& Runoff & $1996-2000$ & Daily \\
Meldro & Air temperature & $1980-2000$ & Daily \\
Gungkar & Precipitation & $1980-2000$ & Daily \\
Pangdo & Precipitation & $1976-2000$ & Monthly \\
& Runoff & $1976-2000$ & Monthly \\
& Runoff & $1997-2000$ & Daily \\
Tangga & Precipitation & $1971-2000$ & Monthly \\
& Runoff & $1971-2000$ & Monthly \\
& Runoff & $1996-2000$ & Daily \\
\hline
\end{tabular}

Table S2. Quality criteria for modeled monthly runoff $\mathrm{R}$ and precipitation data $\mathrm{P}$, driven by CLM ERA 40 meteorological data.

\begin{tabular}{lllccccc}
\hline \multirow{2}{*}{ Period } & Criterion & \multicolumn{2}{c}{ Lhasa } & \multicolumn{2}{c}{ Pangdo } & \multicolumn{2}{c}{ Tangga } \\
& & $\mathrm{R}$ & $\mathrm{P}$ & $\mathrm{R}$ & $\mathrm{P}$ & $\mathrm{R}$ & $\mathrm{P}$ \\
\hline \multirow{2}{*}{$1971-1980$} & $\mathrm{R}^{2}$ & 0.84 & 0.72 & - & - & 0.85 & 0.75 \\
& $\mathrm{NSC}$ & 0.22 & 0.46 & - & - & 0.47 & 0.71 \\
$1981-1990$ & $\mathrm{R}^{2}$ & 0.79 & 0.61 & 0.79 & 0.64 & 0.79 & 0.69 \\
& NSC & 0.14 & 0.17 & 0.22 & 0.51 & 0.33 & 0.69 \\
$1991-2000$ & $\mathrm{R}^{2}$ & 0.79 & 0.71 & 0.78 & 0.75 & 0.80 & 0.76 \\
& NSC & 0.49 & 0.50 & 0.56 & 0.73 & 0.61 & 0.76 \\
$1996-2000$ & $\mathrm{R}^{2}$ & 0.88 & 0.78 & 0.87 & 0.79 & 0.89 & 0.78 \\
& NSC & 0.85 & 0.70 & 0.86 & 0.79 & 0.88 & 0.77 \\
& $\mathrm{R}^{2}$ & 0.80 & 0.68 & 0.78 & 0.72 & 0.81 & 0.73 \\
& NSC & 0.31 & 0.39 & 0.39 & 0.66 & 0.48 & 0.72 \\
\hline
\end{tabular}


Table S3. Changes in glacial coverage and stored ice water reservoir in the Lhasa River basin for the CLM ECHAM5 IPCC A1B, A2 and B1 driven scenario model runs.

\begin{tabular}{lcccccc}
\hline \multirow{2}{*}{ Glacier characteristics } & \multirow{2}{*}{$1971-2000$} & Scenario & \multicolumn{2}{c}{$2011-2040$} & \multicolumn{2}{c}{$2051-2080$} \\
& & & & $\Delta[\%]$ & & $\Delta[\%]$ \\
\hline \multirow{2}{*}{ Glacier Area $\left[\mathrm{km}^{2}\right]$} & \multirow{2}{*}{629} & A1B & 395 & -37 & 147 & -77 \\
& & A2 & 406 & -35 & 215 & -66 \\
& & B1 & 392 & -38 & 202 & -68 \\
\hline \multirow{2}{*}{ Ice water reservoir } & 928 & A1B & 686 & -26 & 247 & -73 \\
{$\left[\mathrm{~mm} / \mathrm{km}^{2}\right]$} & & A2 & 731 & -21 & 386 & -58 \\
& & B1 & 682 & -26 & 362 & -61 \\
\hline \multirow{2}{*}{$\begin{array}{l}\text { Mean annual mass } \\
\text { balance }[\mathrm{m}]\end{array}$} & -0.33 & A1B & -0.54 & \multicolumn{2}{c}{-1.23} \\
& & A2 & -0.33 & -1.39 \\
\hline
\end{tabular}

Table S4. Annual modeled average water balance components (precipitation + reduction of ice storage $=$ evapotranspiration + runoff + storage changes of snow cover, soil water content and groundwater) in $\mathrm{mm}$ for the presented gauges in the LRB.

\begin{tabular}{lcrc}
\hline Gauge & \multicolumn{1}{c}{$1971-2000$} & $2011-2040(\mathrm{~A} 1 \mathrm{~B})$ & \multicolumn{1}{c}{ 2051-2080 (A1B) } \\
\hline Outlet & $630+7=207+429+1$ & $621+8=231+399-1$ & $596+9=263+342+0$ \\
Lhasa & $627+6=206+425+0$ & $613+5=233+386-1$ & $590+5=267+328+0$ \\
Tangga & $624+7=190+440+1$ & $604+6=219+392-1$ & $581+6=252+335+0$ \\
Pangdo & $621+9=183+446+1$ & $601+7=212+397-1$ & $578+7=244+341+0$ \\
Yangbajing & $657+20=177+499+1$ & $662+46=191+521-4$ & $621+62=209+474+0$ \\
\hline
\end{tabular}

Table S5. Values for runoff originating from liquid rainfall, snow-melt and ice-melt in $\mathrm{mm}$ for the presented gauges in the LRB.

\begin{tabular}{llll}
\hline Gauge & \multicolumn{1}{c}{$1971-2000$} & \multicolumn{1}{c}{$2011-2040(\mathrm{~A} 1 \mathrm{~B})$} & \multicolumn{1}{c}{$2051-2080(\mathrm{~A} 1 \mathrm{~B})$} \\
\hline Outlet & $240+177+12=429$ & $250+139+10=399$ & $248+84+10=342$ \\
Lhasa & $232+184+9=425$ & $234+146+6=386$ & $234+89+5=328$ \\
Tangga & $221+208+11=440$ & $217+165+10=392$ & $227+100+8=335$ \\
Pangdo & $214+219+13=446$ & $211+176+10=397$ & $226+106+9=341$ \\
Yangbajing & $245+198+56=499$ & $300+154+67=521$ & $319+87+68=474$ \\
\hline
\end{tabular}


Table S6. Values of ice-melt / snow-melt water release on glacier surfaces / non-glacierized areas of the subbasins for the presented gauges in the LRB in $\mathrm{mm}$.

\begin{tabular}{llll}
\hline Gauge & \multicolumn{1}{c}{$1971-2000$} & \multicolumn{1}{c}{ 2011-2040 (A1B) } & \multicolumn{1}{c}{ 2051-2080 (A1B) } \\
\hline Outlet & $12 / 6 / 171$ & $10 / 5 / 134$ & $10 / 3 / 81$ \\
Lhasa & $9 / 4 / 180$ & $6 / 4 / 142$ & $5 / 2 / 87$ \\
Tangga & $11 / 5 / 203$ & $10 / 4 / 161$ & $8 / 3 / 97$ \\
Pangdo & $13 / 6 / 213$ & $10 / 6 / 170$ & $9 / 3 / 103$ \\
Yangbajing & $56 / 30 / 168$ & $67 / 30 / 124$ & $68 / 18 / 69$ \\
\hline
\end{tabular}

\section{Supplementary model details}

\section{Meteorological Data Extrapolation}

The meteorology compontent of PROMET and SCALMET supplies every grid cell with hourly values of precipitation, air temperature, air humidity, incoming shortwave and longwave radiation, air pressure and wind speed.

For the 100 m elevation levels of the glacier in the subscale approach of SURGES, air temperature, air pressure and wind speed are extrapolated, wet-bulb temperature is then calculated in iteratively solving the psychrometer formula.

The air temperature $\mathrm{T}[\mathrm{K}]$ and air pressure $\mathrm{P}[\mathrm{hPa}]$ are calculated for the various glacier levels. According to the present surface elevation zs $[\mathrm{m}]$, the level air temperature $\mathrm{Tl}[\mathrm{K}]$ is determined by extrapolating the air temperature $\mathrm{T}[\mathrm{K}]$ of the raster cell with the mean elevation $\mathrm{zgc}[\mathrm{m}]$, assuming a linear, either dry or moist adiabatic lapse rate $\Gamma\left[\mathrm{K} \mathrm{m}^{-1}\right]$ :

$\mathrm{Tl}=\mathrm{T}+\Gamma(\mathrm{zgc}-\mathrm{zs})$

The dry adiabatic lapse rate is set to $0.0098 \mathrm{~K} \mathrm{~m}^{-1}$ as the quotient of the gravitational acceleration go of $9.81 \mathrm{~m} \mathrm{~s}^{-2}$, and the specific heat capacity of dry air at a constant air pressure CP of $1,004.67 \mathrm{~J} \mathrm{~kg}^{-1} \mathrm{~K}^{-1}$. The moist adiabatic lapse rate is determined by the process of condensation of water vapour, so that latent heat is released. Since this process depends on air temperature, the gradient is inversely proportional to air temperature and varies between 0.003 and $0.009 \mathrm{~K} \mathrm{~m}^{-1}$. In this study it is set to an average value of $0.0065 \mathrm{~K} \mathrm{~m}^{-1}$ for an air pressure of $1,000 \mathrm{hPa}$ and an air temperature of $273.15 \mathrm{~K}$.

The level air pressure $\mathrm{PI}[\mathrm{hPa}$ ] is calculated by the barometric formula with the gravitational acceleration on Earth go $\left[9.81 \mathrm{~m} \mathrm{~s}^{-2}\right]$, the molar mass of the atmosphere $\mathrm{M}\left[0.028964 \mathrm{~kg} \mathrm{~mol}^{-1}\right]$ and the universal gas constant for air $\mathrm{R}\left[8.3143 \mathrm{Nm} \mathrm{mol}^{-1} \mathrm{~K}^{-1}\right]$ :

$P_{I}=P\left(1+\frac{\Gamma\left(z_{s}-z_{g c}\right)}{T}\right)^{\frac{g_{o} M}{R \Gamma}}$

As the wind speed on a glacier is different from the wind above nonglacier areas, as provided by the climate model, it has to be adopted. The glacier wind $v$, a katabatic flow over glaciers is caused by the 
differences in heat between the snow-free, surrounding areas of a glacier and the comparatively cold glacier surface. The glacier wind is characterized by speeds of 3 to $5 \mathrm{~m} \mathrm{~s}^{-1}$ and increases with proximity to the glacier tongue (Weber 2008). As it is very common over melting surfaces (Oerlemans and Grisogono 2002), it is considered in SURGES in a rather simple way for air temperatures above $0^{\circ} \mathrm{C}$ :

$\mathrm{vl}=\mathrm{v}+0.0015 \mathrm{v}(\mathrm{z}-\mathrm{zs})$

The lower limit of the level glacier wind $\mathrm{vl}\left[\mathrm{m} \mathrm{s}^{-1}\right]$ is given by half of the wind speed of the grid cell $\mathrm{v} / 2$, whereas the upper limit $\mathrm{vl}$,max is determined by a simple parameterization of the maximum velocity of the glacier wind using air temperature according to Kuhn (1978) as follows:

$\mathrm{vl}, \max =0.61 \mathrm{~T}$

For differentiation of rain from snowfall by iteratively solving the psychrometer formula, the wetbulb temperature Tw $[K]$ is calculated for all levels, considering the water vapour pressure e $[\mathrm{hPa}]$, the saturation vapour pressure of a wet surface Ew [hPa], the specific heat of air $\mathrm{cP}\left[\mathrm{J} \mathrm{kg}^{-1} \mathrm{~K}^{-1}\right]$ at a constant air pressure $\mathrm{P}[\mathrm{hPa}]$ and the latent heat of vaporization $\mathrm{r}\left[\mathrm{J} \mathrm{kg}^{-1}\right]$ :

$e=E_{w}-\frac{c_{p} P}{0.623 r}\left(T-T_{w}\right)$

The saturation vapour pressure of a wet surface $E_{w}[\mathrm{hPa}]$ is computed with the Magnus formula.

For simulation of the longwave radiation balance $Q_{1}\left[W \mathrm{~m}^{-2}\right]$, the incoming longwave

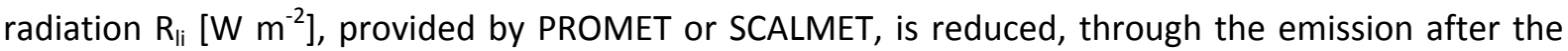
Stefan-Boltzmann Law. In addition to the emissivity $\varepsilon$, which is 1 for snow and 0.98 for ice, it also depends on the current level surface temperature $T_{S}[K]$, which is set to $273.15 \mathrm{~K}$ for air temperatures above freezing point. If the air temperature is below this, the surface temperature is determined in an iterative procedure closing the energy balance (Strasser 2008):

$Q_{l}=R_{l i}-\sigma \cdot \varepsilon \cdot T_{S}^{4}$

All the other meteorological variables, e.g. precipitation or incoming radiation, are assumed to be constant throughout the grid cell and are taken from the meteorology component of PROMET or SCALMET without any adaptation. There is no indication in which way the intensity of precipitation varies on the area of one square kilometer. Additionally, wind- and leeward effects are not considered in the modeling approach, because the approach has been developed not for a single glacier but for all glaciers of a mesoscale river basin. Nevertheless, the approach can be enhanced in adding a detailed radiation model considering shading.

\section{The energy balance calculations in SURGES}

In order to determine the mass gain and loss of the glacier, the changes of the mass balance on its surface have to be calculated. The following calculation steps are similar for a snow and ice layer, only differentiated by varying material properties, e.g. the albedo $\alpha$. The algorithms are mainly based on Weber (2008) and on the snow model ESCIMO, which was implemented in the snow component of PROMET (Strasser and Mauser, 2001, Prasch et al., 2008b), and enhanced and validated in various studies (Mauser et al., 2007, Prasch et al., 2008a, b, Strasser ,2008). 
First, the energy balance $E\left[\mathrm{~W} \mathrm{~m} \mathrm{~m}^{-2}\right]$ of the surface is calculated, taking into account the radiation balance $Q\left[\mathrm{~W} \mathrm{~m}{ }^{-2}\right]$, the latent and sensible heat fluxes $L E\left[W \mathrm{~m}^{-2}\right]$ and $\mathrm{H}\left[\mathrm{W} \mathrm{m^{-2 }}\right.$, and the energy supplied by solid or liquid precipitation $\mathrm{A}\left[\mathrm{W} \mathrm{m}^{-2}\right]$ :

$E=Q+L E+H+A$

The radiation balance consists of the sum of the shortwave $\mathrm{Q}_{s}\left[\mathrm{~W} \mathrm{~m}^{-2}\right]$ (Eq. S8) and longwave radiation balance $Q_{1}\left[\mathrm{~W} \mathrm{~m}^{-2}\right]$ (Eq. S10). The amount of incoming direct $R_{\text {dir }}\left[\mathrm{W} \mathrm{m}^{-2}\right]$ and diffuse solar radiation $R_{\text {dif }}\left[\mathrm{W} \mathrm{m}^{-2}\right]$, which is partly reflected due to the albedo $\alpha$, forms the shortwave radiation balance:

$Q_{s}=(1-\alpha)\left(R_{\text {dir }}+R_{\text {dif }}\right)$

Since solar radiation contributes most to the surface energy under melting conditions, the albedo is of great importance. For conditions of snow and ice, it depends on many factors, e.g. grain size, density, impurity content, solar elevation etc. In this study, the albedo is set to 0.5 in the case of snow-free ice for the Lhasa River catchment, which is a relatively high value for glacier ice, similar to clean ice (Paterson 1994). This value was chosen because of extremely dry and clean air on the Tibetan Plateau due to its elevation and latitude. In the case of snow covering the glacier, the albedo of freshly fallen snow (0.9) decreases due to changes in grain size, density and impurity content of the snow surface. The ageing curve of the albedo of freshly fallen snow is simulated following Rohrer (1992) (Eq. S9)). The exponential reduction during the time interval $\Delta t[s]$ since the last considerable snow fall $(0.5 \mathrm{~mm}$ per hour) differs between air temperatures above and below freezing point, accounted for by changing recession coefficients $k$. For air temperatures above freezing point, $k$ is set to 0.05 per day, whereas for air temperatures below, it is set to 0.12 per day. The decrease continues until a minimum value $\alpha_{\min }$ of 0.55 is reached, or until the next considerable snowfall happens. In this case it is reset to the maximum value of 0.9 .

$\alpha=\alpha_{\min }(t)+\left(\alpha(t-1)-\alpha_{\min }\right) e^{-k \frac{1}{24}}$

For simulation of the longwave radiation balance $\mathrm{Q}_{1}\left[\mathrm{~W} \mathrm{~m}^{-2}\right]$ (Eq. 5), the incoming longwave radiation

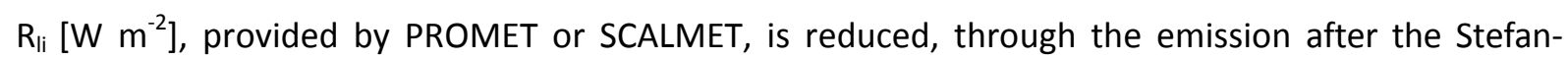
Boltzmann Law, with the Stefan-Boltzmann constant $\sigma$ of $5.67 \cdot 10^{-8} \mathrm{~W} \mathrm{~m}^{-2} \mathrm{~K}^{-4}$. In addition to the emissivity $\varepsilon$, which is 1 for snow and 0.98 for ice, it also depends on the current surface temperature $\mathrm{T}_{\mathrm{S}}[\mathrm{K}]$, which is set to $273.15 \mathrm{~K}$ for air temperatures above freezing point. If the air temperature is below this, the surface temperature is determined in an iterative procedure closing the energy balance (Strasser 2008).

$Q_{l}=R_{l i}-\sigma \cdot \varepsilon \cdot T_{S}^{4}$

The turbulent fluxes are computed consistent with Weber (2008). High mountain conditions above glaciers such as high wind speeds, dependency on elevation and changing surface roughness are particularly closely considered in the formulation. The sensible heat flux $\mathrm{H}\left[\mathrm{W} \mathrm{m}^{-2}\right]$ is proportional to the specific heat of air $c_{p}\left[\mathrm{Jg}^{-1} \mathrm{~K}^{-1}\right]$, and to the difference between the air temperature $T[K]$ and the surface temperature $T_{s}[K]$ : 
For the latent heat flux LE [W $\left.\mathrm{m}^{-2}\right]$ the latent heat of vaporization $r\left[\mathrm{Jg}^{-1}\right]$ (Eq. S12) and the difference between the specific humidity of the air sh $\left[\mathrm{kg} \mathrm{kg}^{-1}\right]$ Fehler! Verweisquelle konnte nicht gefunden werden. and at the surface $\mathrm{sh}_{\mathrm{s}}\left[\mathrm{kg} \mathrm{kg}^{-1}\right]$ are taken into account:

$r=2500827-2360 \cdot(T-273.15)$

$L E=0.0092 \cdot \rho_{a} \cdot r \cdot R_{w T} \cdot v \cdot\left(s h-s h_{s}\right)$

Thereby the air density $\rho_{a}\left[\mathrm{~kg} \mathrm{~m}^{-3}\right]$ is calculated with the universal gas constant of air $R_{d}$ of 287 $\mathrm{kg}^{-1} \mathrm{~K}^{-1}$ by:

$\rho_{a}=\frac{P \cdot 100}{R_{d} \cdot T}$

In both equations, $R_{w T}$ stands for a correlation coefficient which describes the turbulent exchange according to Weber (2008). The factor permits an approximate physically-based description of the fluxes in considering the stability of the atmospheric layering due to the air temperature $T[K]$, the surface air temperature $T_{S}[K]$ and the wind speed $v\left[\mathrm{~m} \mathrm{~s}^{-1}\right]$. For stable layering, $R_{w T}$ is proportional to the gradient of the air temperature $T$ and the surface temperature $T_{S}$, while the efficiency of the turbulent exchange decreases with increasing wind speeds $\vee$ Eq. a). The correlation is limited to a value of 0.2 for large temperature gradients in combination with high wind speeds, because this case rarely occurs in nature Eq. b). For a negative temperature gradient, labile layering is assumed. In this case $R_{w T}$ is set to 0.4 Eq. c) (Weber 2008).

$R_{w T}=0.438-0.119 \frac{T-T_{S}}{v}$ for $\mathrm{T}>\mathrm{T}_{\mathrm{S}}$ and $\left(\mathrm{T}-\mathrm{T}_{\mathrm{S}}\right)<3.68 \mathrm{v}$

$R_{w T}=0.2$ for $T>T_{S}$ and $\left(T-T_{S}\right)>3.68 v$

$R_{w T}=0.4$ for $T \leq T_{S}$

In the case of precipitation an advective flux $A\left[\mathrm{~W} \mathrm{~m}^{-2}\right]$ is used to account for the energy balance $E\left[\mathrm{~W} \mathrm{~m}^{-2}\right]$ depending on its phase. As the threshold wet-bulb temperature $T_{w}$ is set at $2^{\circ} \mathrm{C}$, a distinction is made between rain Eq. (S16a) and snowfall Eq. (S166b). In the first case the flux is proportional to the specific heat of water $c_{w}$ of $4,180 \mathrm{~J} \mathrm{~kg}^{-1} \mathrm{~K}^{-1}$, whereas in the second case it is relative to the specific heat of ice $c_{i}$ of $2,100 \mathrm{~J} \mathrm{~kg}^{-1} \mathrm{~K}^{-1}$. Additionally, the amount of precipitation $P R$ [mm] and the difference between air or wet temperature $T[K]$ or $T_{w}[K]$ and surface temperature $T_{S}[K]$ are considered.

$A=P R_{R} \cdot C_{w}(T-273.15)$

Eq. (S16a)

$A=P R_{S} \cdot c_{i}\left(T_{w}-T_{S}\right)$

After these calculations, the energy balance $E\left[\mathrm{~W} \mathrm{~m}^{-1}\right] \mathrm{Eq}$. (S7 S7) is computed. If it is positive, the amount of meltwater $\mathrm{m}[\mathrm{mm}]$ during the time interval $\Delta \mathrm{t}[\mathrm{s}]$ of snow or ice is calculated as follows, where $H_{i}$ is the specific melting heat of ice of $337,500 \mathrm{~J} \mathrm{~kg}^{-1}$ : 
$m=\frac{E \cdot \Delta t}{H_{i}}$

Due to the quick release of glacier meltwater and the generally large amount of surface runoff in the mountains (Lambrecht and Mayer 2009), in SURGES, the melt water $\mathrm{m}$ of glaciers is immediately supplied to the surface runoff of PROMET. By contrast, the meltwater $m$ release of snow is handled similarly to rain, and drains into the soil layers or supplies surface runoff, taking into account varying land cover characteristics.

In order to determine the mass balance per elevation level, the sublimation or resublimation process is also considered, which is especially important in cold, dry regions with high radiation input, as it is the case in the Lhasa River catchment. The mass change conducted by this process se [mm] per time

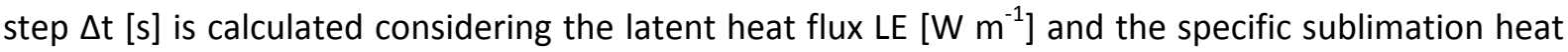
of snow and ice $H_{\text {is }}$ of $2,835,500 \mathrm{~J} \mathrm{~kg}^{-1}$ :

$s e=\frac{L E \cdot \Delta t}{H_{i s}}$

\section{Supplementary model validation of the SURGES model}

Detailed observation data are required for validation of the processes on glaciers, which are generally rare. Additionally, the model algorithms must be non-sensitive to defective input data. Consequently, boundary conditions such as topography and meteorology must be as reliable as possible. For this reason, SURGES is applied to places which fulfil these requirements for validation of the glacier processes. Since neither detailed meteorological station recordings nor glacier observations are available in the Lhasa River basin, the Schneeferner at the Zugspitze in Germany, the Vernagt Ferner in Austria and the gauge of Huben of the Ötztaler Ache in Austria were chosen for validation of the model. Within the framework of GLOWA-DANUBE (www.glowa-danube.de), detailed data describing the geometry and the ice reservoir are provided for the three chosen test sites, sometimes for several time steps. Furthermore, meteorological drivers of a comparatively high spatial and temporal resolution are available in the form of numerous station recordings by the German and Austrian weather service DWD and ZAMG.

The mass balance of a glacier is determined by the accumulation of snow and the ablation of snow and ice afterwards. Several studies have validated snow accumulation and ablation of the PROMET snow component on a local scale by comparing modelled s.w.e. values to observation data at weather stations. The spatial distribution of the modelled snow cover on the catchment scale was compared to observed snow coverage, deduced from NOAA AVHRR images. These studies showed that the model can reproduce snow dynamics at the point and spatial scale (Bach et al. 2008, Prasch et al. 2008b, Strasser and Mauser 2001). In order to determine the model performance on a glacier, a detailed validation study at the Vernagt Ferner in Austria was carried out by Marowsky (2010). In this study, the evolution of snow depth observations at the Vernagt Ferner, at an elevation of 3,000 $\mathrm{m}$ a.s.l. (Braun et al. 2004), are compared with the modelled s.w.e. at this elevation level for the first half of the year 2005 (Escher-Vetter and Weber 2009). Although no evidence of snow quantity can be given, because no snow density observations are available for converting the s.w.e. values into snow depth, the duration of the snow cover is similar. Synchronous accumulation and 
ablation periods can be seen on the chart in Fig. S3. Consequently, the dynamics are reproduced by the model on a glacier. The date of complete snow cover melt is especially important for simulation of the glacier ice-melt, because it determines the duration of the melting period.

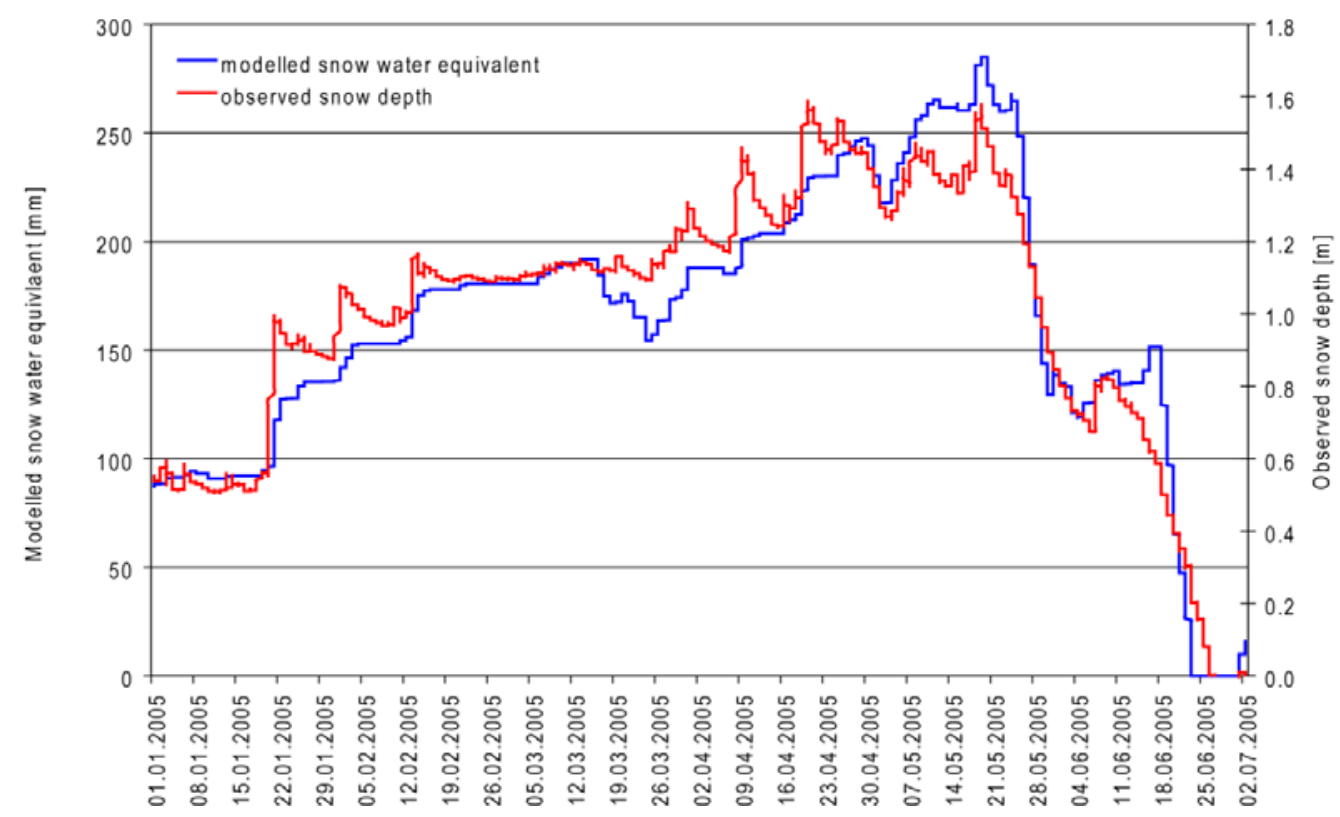

Figure S3. Comparison of the evolution of the modelled snow water equivalent (blue) and the observed snow depth (red) at the Vernagt Ferner (Marowsky 2010, p. 64, modified).

The ice ablation period was validated by Marowsky (2010), in comparing observed ice thickness changes with modelled changes. Fig. S4 shows the comparison for the year 2006. For the measurements of relative ice thickness changes, an ablatometer was installed on the glacier surface (Fig. S4, method 1, blue). With a second instrument, the relative changes of the ice thickness were deduced from observed hydrostatic pressure changes (Figure, method 2, green). Although the absolute values of the observation differ, the strong ablation period during July and the proximate snow cover in August are in accordance and reproduced by SURGES, meaning that the ice ablation period is also captured.

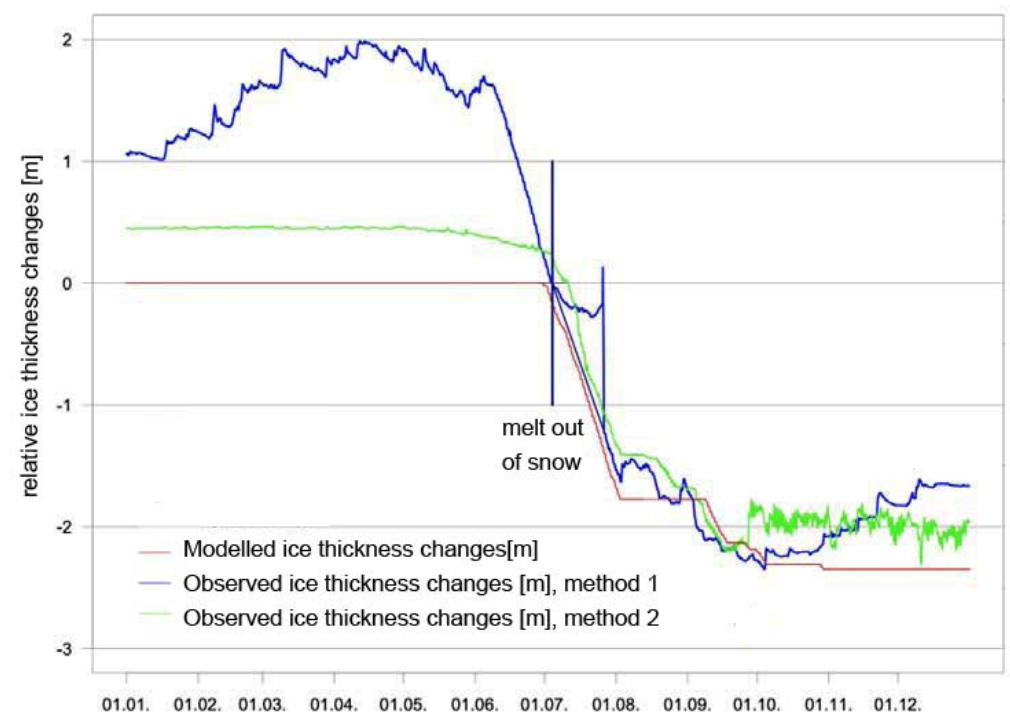

Figure S4. Comparison of modelled (red) and observed (blue and green) ice thickness changes 2006 (Marowsky 2010, p. 66, modified). 
By comparing modelled and observed ice thickness observations on the glacier scale of the Northern Schneeferner at the Zugspitze in Germany from 1970 to 2006, the accurate simulation of glacier development is validated over a long period. Fig. S5 shows the observed ice thickness of the years 1970, 1979, 1990, 2000 and 2006 (red) with the simulated ice thickness (light blue) and the evolution of the snow water equivalent (blue). The observations are correctly reproduced by the model. Furthermore, the period with high snowfall rates during the winters at the beginning of the 1980s and the subsequent gain in ice mass is captured by SURGES. The extraordinarily long ablation period of summer 2003 is also accurately simulated. Although this validation step only offers the comparison at five time steps during this period, it shows the performance of the model over a long time period. Only if snow and ice accumulation and ablation are simulated correctly over the complete period, the observed ice thickness values are reproduced by the model.

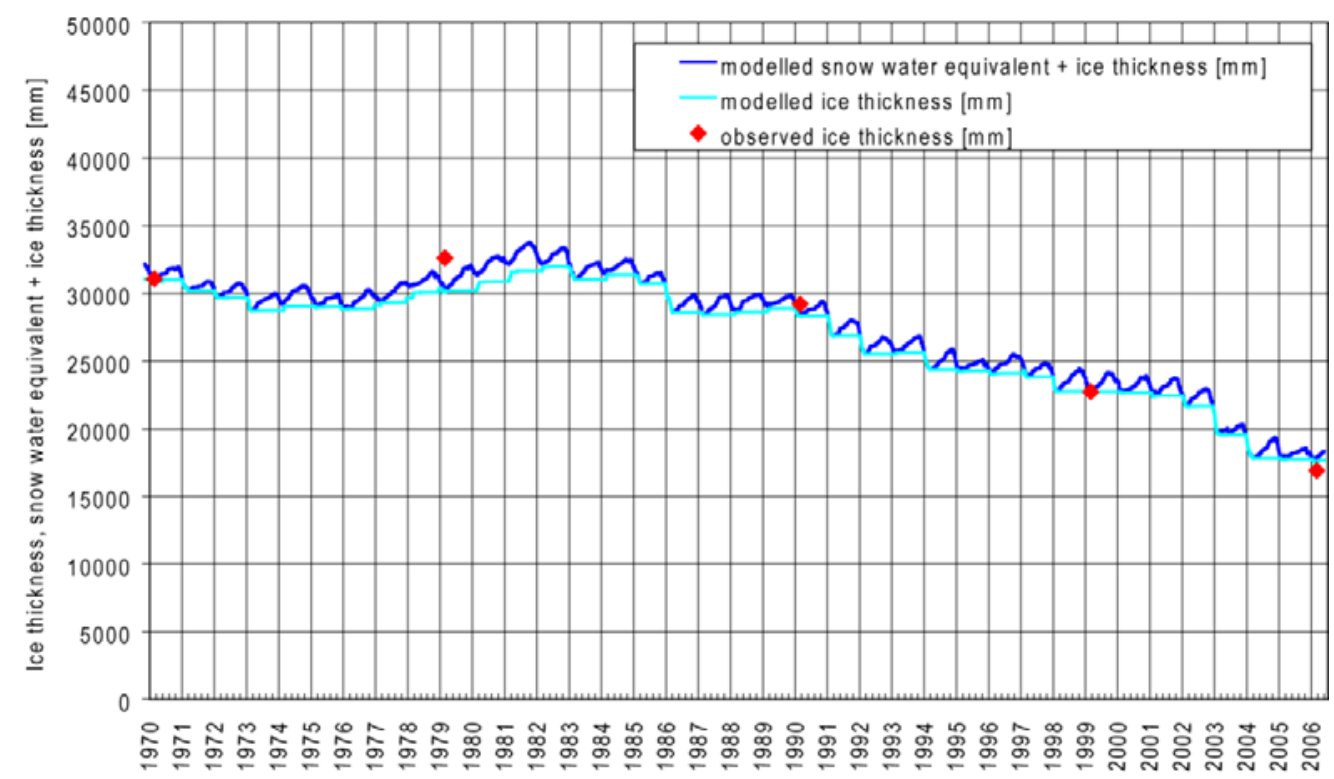

Figure S5. Modelled and observed ice thickness of the Northern Schneeferner at the Zugspitze in Germany (based on Bayerische Gletscher (2009)).

In order to validate glacier geometry changes, the modelled and observed glacier areas were compared for the Northern and Southern Schneeferner as presented in Fig. S6. The original areas of 1979 are illustrated in black, whereas the grey areas show the extent mapped in 2006. The blue areas symbolize the modelled areas of the year 2006. The comparison shows deviations at the edges of the glaciers, in particular at the glacier tongues, where the model result is falsified by anthropogenic modifications in the skiing area (Marowsky 2010). Additionally, ice redistribution is not considered in this simulation. The ice flow is low because of the small extent of the Zugspitze glaciers, and so this effect can be neglected. Since the longwave radiation flux of neighbouring snow-free rocks is not simulated in SURGES, the accelerated melting during the breakup of glaciers in different parts with increasing surrounding rock areas is not reproduced. In this case, the melting is simulated too slowly, and a uniform ice thickness distribution on the elevation levels enforces this effect on the edges. In contrast, the melt from thick areas is simulated too quickly, so a conclusion of at least a partial compensation by the two effects can be drawn. Nevertheless, the congruence over a modelling period of 26 years dominates, especially in the parts of the glaciers where most ice is stored. 


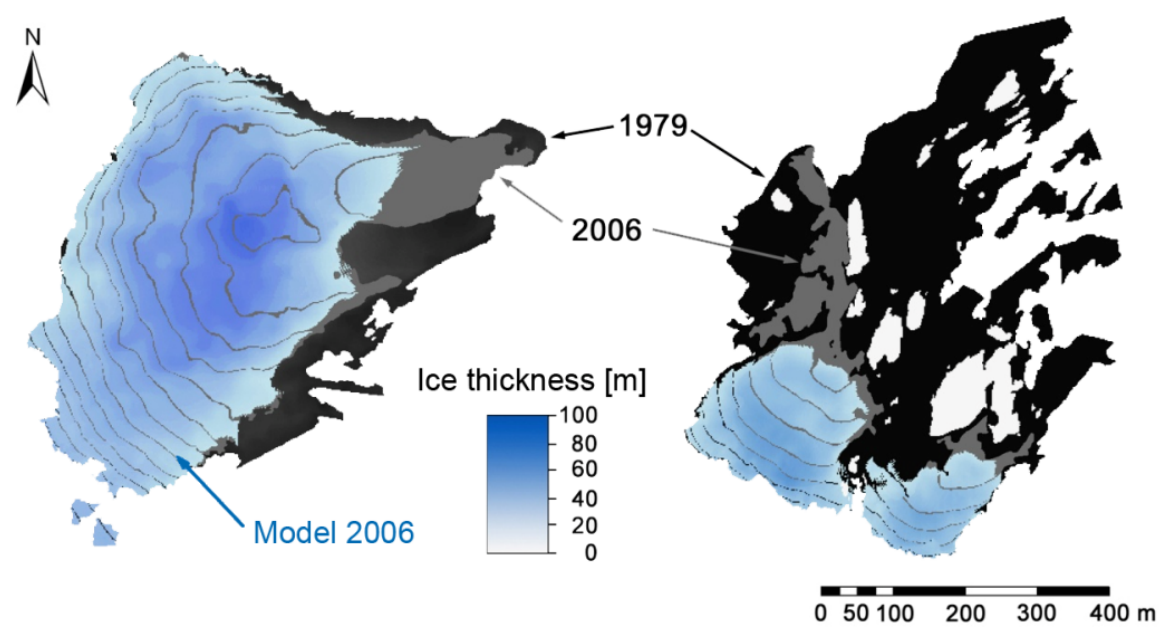

Figure S6. Comparison of modelled (blue) and observed glacier extent (grey and black) for the Northern (left) and Southern (right) Schneeferner at the Zugspitze in Germany between 1979 and 2006 (Marowsky 2010, p.70, modified).

A similar validation study was carried out for a larger glacier $\left(8 \mathrm{~km}^{2}\right)$, the Vernagtferner in the Oetztal Alps in Austria.

Since this study focuses on the impact of glacier melt on the runoff, the next step is to validate the reproduction of the runoff by the model framework in an alpine glacierized catchment. The necessity of the subscale approach to simulate the glaciers on the $1 \times 1 \mathrm{~km}$ size is also tested. As described above, the Huben gauge of the Ötztaler Ache, with a glacial coverage of 8 percent, was chosen.

In order to determine the influence of ice-melt on runoff, the results of three different model runs were analysed. In the first model run, the runoff was simulated without considering glaciers and subsequently the ice-melt contribution. In the second model run, the glacier ice reservoir was equally distributed on the $1 \times 1 \mathrm{~km}$ grid cell, and in the third simulation, the glaciers were considered in the subscale approach as introduced in section Fehler! Verweisquelle konnte nicht gefunden werden.. The results for the period from 1.1.2000 to 31.12.2005 were compared to discharge observations by Huben. This period was selected because the glacier inventory for this basin reproduced the status of the year 2000. Table S7 lists the coefficient of determination $R^{2}$ and the Nash-Sutcliffe efficiency coefficient, in the following referred to as NSC, as quality criteria for the various model runs, whereas Figs. S7 and S8 show the runoff course of the different simulations for two years from 1.1.2003 to 1.1.2005.

Table S7. Quality criteria for the simulated runoff of different model runs at the Huben gauge of the Ötztaler Ache from 1.1.2000 to 31.12.2005.

\begin{tabular}{lccc}
\hline Model runs & $\begin{array}{c}\text { without ice, } \\
\text { subscale approach }\end{array}$ & $\begin{array}{c}\text { with ice, no } \\
\text { subscale approach }\end{array}$ & $\begin{array}{c}\text { with ice, subscale } \\
\text { approach }\end{array}$ \\
\hline $\begin{array}{l}\text { Coefficient of determination } \\
\begin{array}{l}\text { Nash-Sutcliffe efficiency } \\
\text { coefficient }\end{array}\end{array}$ & 0.66 & 0.57 & 0.82 \\
\hline
\end{tabular}




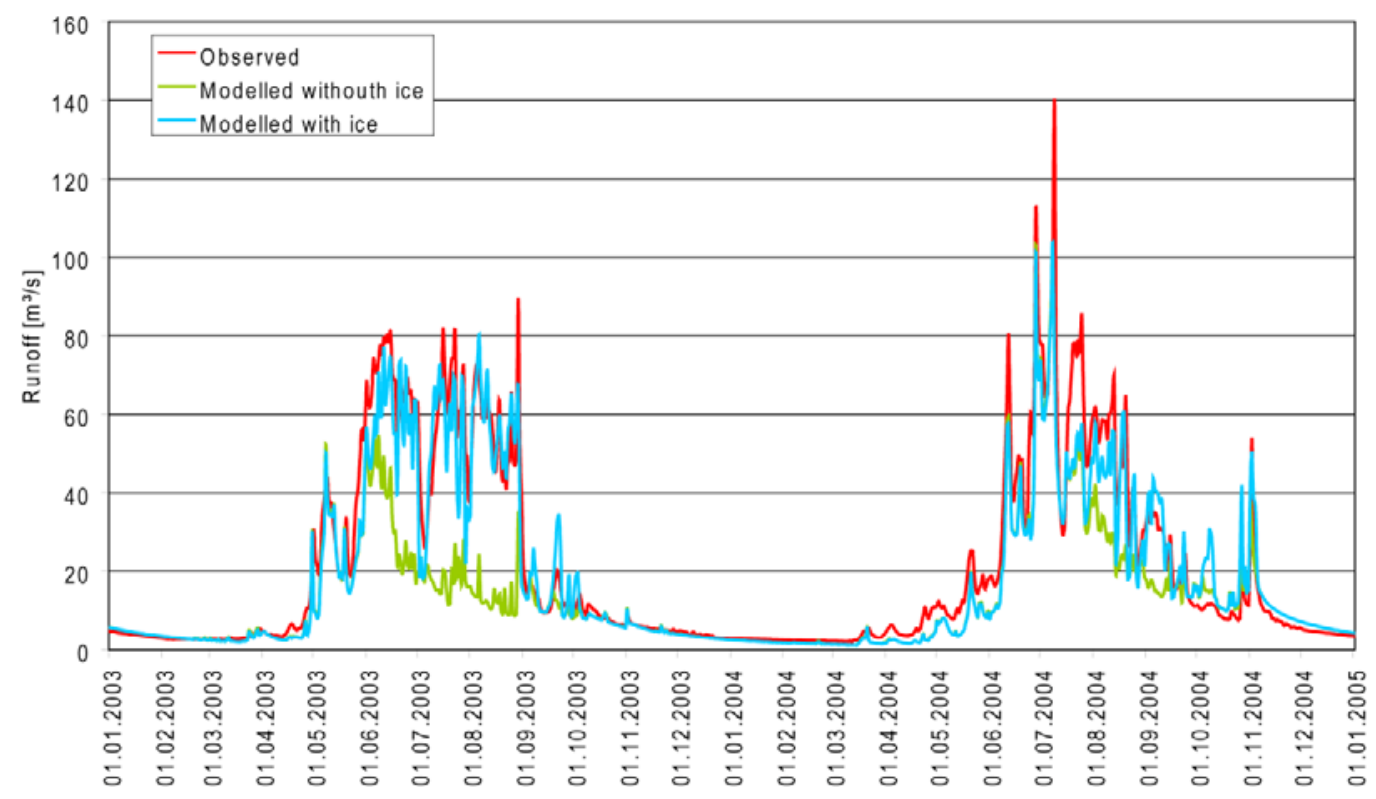

Figure S7. Comparison of modelled daily runoff without considering ice-melt water (green), and with ice-melt water (turquoise), to observed values (red) at the gauge in Huben of the Ötztaler Ache from 1.1.2003 to 1.1.2005.

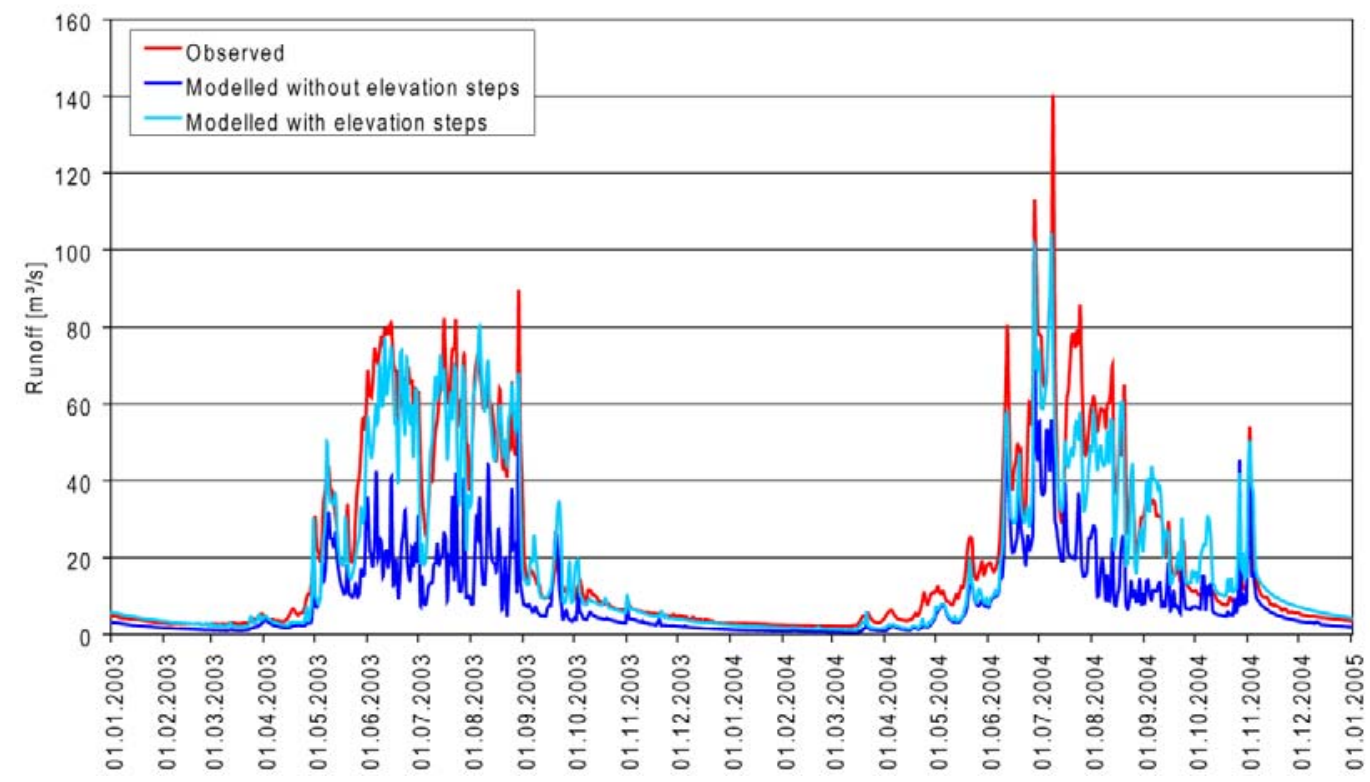

Figure S8. Comparison of modelled daily runoff without subscale approach (blue), and with subscale approach (turquoise), to observed values (red) at the gauge in Huben of the Ötztaler Ache from 1.1.2003 to 1.1.2005.

The clear improvement in the coefficient of determination and the NSC from 0.57 or 0.29 respectively to 0.82 in the model run, considering ice on the subscale, shows the positive influence of this approach on the runoff. The comparison of the quality criteria for the first two model runs even shows that the influence of the ice-melt on runoff is less than the influence of the subscale approach, because the criteria are higher for the subscale simulations without considering ice than for the results with ice, equally distributed over the complete grid cell. A comparison of development of the 
runoff of the different model runs with the observed discharge in Huben confirms and clarifies the result.

Simulating the glacier meltwater release with SURGES reproduces the runoff, whereas a considerable amount of water is missed during the summer months in the simulation without ice-melt. The glacier meltwater clearly contributes to the runoff, especially in the case of the extraordinary summer of 2003. In June, when the lower glacierized elevation levels become snow-free, a noticeable ice-melt water contribution to runoff starts. The percentage rises with the increase of snow-free glacier areas and culminates in August. With the first snowfalls in the highest mountain areas in September, the snow-free areas are reduced and the percentage of ice-melt decreases. During winter when the glaciers are completely covered with snow, meltwater release from the glaciers almost stops. This development of meltwater release is similar across years, but the amount, the beginning and end of ice-melt contribution depends on the prevailing weather conditions. In 2004, glacier melt did not start until July and contributed less water to the runoff in Huben than in 2003 (see Fig. S8). The amount nonetheless remains essential for the simulation of the daily discharge.

A comparison of the second model run with the equally distributed ice on the grid cell clarifies the need of the subscale approach. The dynamics of the glacier melt water release cannot be reproduced in considering the ice storage as uniformly distributed on the grid cell of one square kilometre, and so the dynamics and the amount of the runoff peaks are not reproduced in detail. The reason for the deviations is the simultaneous melt of the snow cover of the entire grid cell. No melt water is contributed from the ice at the beginning of the melting period, whereas water is released from the whole grid cell after the snow melt. Furthermore, the snow cover of some glacierized grid cells in the highest mountains might outlast the whole summer season. As a consequence, no melt water is released from these areas, whereas the ice cover of the lower grid cells with thin ice layers melts away quite quickly. Additionally, glacierized areas are larger when distributed to the whole grid cell, and determine the amount of melt water release. Accordingly, the water release at Huben is less than in the simulation with consideration of the glacier's area-elevation distribution. Since the meltwater release from the glacier is determined by the snow-free glacier area, the dynamics for the runoff cannot be captured without considering the area-elevation distribution of the glacier. The coexistence of snow-covered and snow-free parts on one grid cell is also the reason for the improved reproduction of runoff dynamics in the subscale approach without ice in the example introduced (Figure S7).

This step in the validation process also shows the performance of the hydrological model PROMET in the reproduction of the runoff in Huben. The validation of the components of PROMET are not shown, because several studies have proven the quality of the model, including Mauser and Bach (2009), Strasser and Mauser (2001) and Ludwig and Mauser (2000).

\section{References}

Bach, H., Appel. F., and Mauser, W.: Provision of snow information from satellite data within Polar View and application example for a mesoscale Alpine catchment using PROMET, in: Proceedings Alpine*Snow*Workshop, edited by Strasser, U. and Vogel. M., Berchtesgaden National Park research report, 53, Berchtesgaden, Germany, 18-23, 2008.

Bayerische Gletscher: http://www.bayerische-gletscher.de, last access: 5.6.2009. 
Braun, L.N., Weber, M., and Schulz, M.: Consequences of climate change for runoff from Alpine regions, Ann. Glacio., 31, 19-25, 2004.

Escher-Vetter, H. and Weber, M.: Determination of snow accumulation in high mountains based on data from climate stations, Annalen der Meteorologie, $30^{\text {th }}$ ICAM, Rastatt, Germany, May 2009, 104-105, 2009. Available at http://www.glaziologie.de/download/ICAM2009-AnnMeteo44.pdf.

Haeberli, W. and M. Hoelzle: Application of inventory data for estimating characteristics of and regional climate-change effects on mountain glaciers: a pilot study with the European Alps. Ann. Glaciol., 21, 206-212, 1995.

Kuhn, M.: Die Höhe des Geschwindigkeitsmaximums im Gletscherwind als Parameter des Wärmehaushalts, Arbeiten aus der Zentralanstalt für Meteorologie und Geodynamik, 31, 69/169/8, Vienna, Austria, 1978.

Lambrecht, A. and Mayer, Ch.: Temporal variability of the non-steady contribution from glaciers to water discharge in western Austria. J. Hydrol., 376, 353-361, 2009.

Ludwig,R. and Mauser, W.: Modelling catchment hydrology within a GIS based SVAT-model framework, Hydrol. Earth Syst. Sc., 4, 239-249, 2000.

Marowsky, K.: Die Validierung des Gletschermodells SURGES am Beispiel von Vernagtferner sowie Nördlichem und Südlichem Schneeferner, dilpoma thesis at the commission for glaciology oft he Bavarian Academy of Sciences and the Catholic University of Eichstätt-Ingolstadt, Germany, 147 pp., 2010.

Mauser, W. and Bach, H.: PROMET - Large scale distributed hydrological modeling to study the impact of climate change on the water flows of mountain watersheds, J. Hydrol., 376, 362-377, doi:10.1016/j.hydrol.2009.07.046, 2009.

Mauser, W., Prasch, M., and Strasser, U.: Physically based Modelling of Climate Change Impact on Snow Cover Dynamics in Alpine Regions using a Stochastic Weather Generator, in: MODSIM 2007 International Congress on Modelling and Simulation, edited by Oxley, L and Kulasiri, D., Modelling and Simulation Society of Australia and New Zealand, 2138-2145, 2007.

Oerlemans, J. and Grisogono, B.: Glacier winds and parameterisation of the related surface heat fluxes. Tellus, 54 A, 440-452, 2002.

Paterson, W.S.B. The Physics of Glaciers. Third Edition. Butterworth-Heinemann, Oxford, 481,1994.

Prasch, M., Bernhardt, M., Weber, M., Strasser, U., and Mauser, W.: Physically based modelling of snow cover dynamics in Alpine regions, in: Managing Alpine Future - IGF Forschungsberichte, 2, edited by Borsdorf, A., Stötter, J., and Veulliet, E., Verlag der Österreichischen Akademie der Wissenschaften, Innsbruck, Austria, 322-330, 2008 a.

Prasch, M., Strasser, U., and Mauser, W.: Validation of a physically based snow model for the simulation of the accumulation and ablation of snow (ESCIMO), in: Proceedings Alpine*Snow*Workshop edited by Strasser, U. and Vogel, M., Berchtesgaden National Park research report, 53, Berchtesgaden, Germany, 78-91, 2008b.

Rohrer, M.B. Die Schneedecke im Schweizer Alpenraum und ihre Modellierung. Züricher Geographische Schriften 49, 178, 1992.

Strasser, U. and Mauser, W.: Modelling the spatial and temporal variations of the water balance for the Weser catchment 1965-1994. J. Hydrol., 254, 199-214, 2001

Strasser, U.: Modelling of the mountain snow cover in the Berchtesgaden National Park, in: Berchtesgaden National Park research report, 55, Berchtesgaden, Germany, 104 pp., 2008.

Weber, M.: Mikrometeorologische Prozesse bei der Ablation eines Alpengletschers. Abhandlungen Bayerische Akademie der Wissenschaften, Mathematisch -Naturwissenschaftliche Klasse, Neue Folge, 177, Munich, Germany, 258 pp., 2008. 